\title{
From the Editors' Desks
}

Welcome to volume seven, or as we like to call it in production, Vulcan 'oo7'. Some may have noticed that vol. 6 had a subtitle change, but as that happened in final production there was no time to get an editorial in that issue to explain it. We have changed from "The international journal for the social history of military technology" to just simply "The journal of the history of military technology." It is important to emphasize that in dropping 'international' and 'social' from the subtitle, we are in no way abandoning those topics, and remain committed to a wide range of geographical, chorological (and chronological), and disciplinary approaches to the history of technology. It was just that the subtitle was a mouthful, was perhaps unnecessarily complicated, and we realized that modern history of technology is both international and social by its nature. We'll be happy to receive manuscripts and books for review addressing warfare from any of these directions. We will also continue to encourage any narrowly technical contributions towards broader analytical approaches that help explain the history of military technology.

From THE EDITOR: Recently I found out that Vulcan was in fact one of the early considerations in $195^{8}$ for the journal of the Society for History of Technology (sнот), which eventually became Technology \& Culture (they also considered Technologia and History of Technology; Hughes 2009, 597). It is interesting to know that the idea of Vulcan as indicative of technology resonates more broadly than his limited historical position - the son of Jupiter and Juno and the master smith on Lemnos that Mars used to forge his weapons and armor, including Achilles' shield - as the inventor of arms and of working fire and iron and, indeed, all metals through pyromancy. It is also curious to know that all of his purported offspring were accursed in some way and brought misery and pillage to the lands in which they lived (King 1750, 100-106).

This issue is a themed one on technological determinism, long a concern of historians of technology and often, though perhaps only implicitly, historians of war. I would like to thank David Zimmerman, author of one of the pieces herein, for the idea to do an issue on the topic, and to the other contributors who were interested in taking up the challenge to consider it. I am sure that they have not said the last word on topic, but I do believe that they have 
helped clarify essential features that we all too often gloss over or tacitly ignore (or embrace). For my own interests, which span the premodern through the second industrial revolution, the clarification that something happened there, as well as the macro-micro distinction that Alex Roland makes, are very valuable insights. Vulcan would welcome further case studies, historiographic analyses, or thought pieces on the topic.

For the purposes of this issue, there is one story of Vulcan which is trenchantly relevant. When Mars was caught in adulterous carnal embrace with Venus, the gods decreed that he must pay a fine, and that it was to be paid to Vulcan: "Not Mars his Swiftness cou'd the God defend / From limping Vulcan's most unerring Snare, / But in it he surpriz'd th' adult'rous Pair." And for fear that Mars and Venus would flee the debt, Vulcan promised to "not release them from the binding Chain, / Till I that Dowry have receiv'd again" (Potter 1751, 2: 300-302). And thus it was that Vulcan, in making his chain, could bind even the gods to his will and to payment of their debt. Allowing the chain to stand as a synecdoche of technology, nothing could more clearly encompass the concept of technological determinism. As I have tried to indicate in my own introductory essay for this issue, our attachment to technological determinism is indeed deep, even while we decry that such a belief and behavior could ever be true. We are often seemingly chained by our technologies - chains that we ourselves have forged - but this myth also reminds us that we must, eventually, pay our debt.

\author{
Steven A. Walton \\ Michigan Tech \\ sawalton@mtu.edu
}

From the Book Review Editor: It is my privilege to serve as the first book review editor for Vulcan. In this issue you'll find insightful critiques by a variety of scholars on books that address a varied set of topics, all dealing with military technology, from the musket to Star Wars. It is our hope that in forthcoming issues, the titles we review will be as diverse and interesting. Indeed, we have several titles needing qualified reviewers right now. For a list of titles, please contact me directly. Also, if you know of recent relevant books that would be good for review, please let me know and I can request them from the publishers. Finally, we are interested in developing some essay reviews on classic works on the topic of war and technology; if you have interest in writing such a piece, please contact either of the editors.

\author{
Rich Hamerla \\ University of Oklahoma \\ rhamerla@ou.edu
}




\section{Works Cited}

Hughes, Thomas P. 2009. "s нот Founders' Themes and Problems," Technology \& Culture 5o, no. 3: 594-599.

King, William. 1750. An Historical Account of the Heathen Gods and Heroes; Necessary for the Understanding of the Ancient Poets. London: Henry Lintot.

Potter, John. 1751. Archceologia Grceca: or, the Antiquities of Greece, $7^{\text {th }}$ ed. London: G. Strahan, et al. 